\title{
PENGEMBANGAN SKALA MODAL SOSIAL PADA REMAJA
}

\author{
Selviana \\ Fakultas Psikologi, Universitas Persada Indonesia, Jl. Diponegoro No. 74, Jakarta Pusat 10430, Indonesia
}

Korespondensi:

e-mail: selvi.humble@gmail.com

\begin{abstract}
Adolescents are surrounded by social environment in their daily life which becomes their social capital. In this study, the social capital includes significant people in adolescents' life, such as: parents, teachers, and friends, from which the measurement of adolescent social capital is based upon. Respondents in this study consisted of 250 adolescents, of which 46 percent were men. The results of psychometric tests demonstrated a good validity and reliability of the developed scale through internal consistency and construct validity testing. The scale was proficient in measuring the similar constructs of social capital: social interaction, trust, and shared vision. Given the good psychometric properties, the developed scale is reliable to be used to measure social capital for adolescents.
\end{abstract}

Article history:

Received 13 August 2018

Received in revised form 7 January 2019

Accepted 14 January 2019

Available online 4 April 2019

Keywords:

adolescents;

social capital;

psychometry;

scale development

\begin{abstract}
Abstrak - Dalam kehidupan sehari-hari, remaja memiliki lingkungan pergaulan yang menjadi modal sosialnya (social capital). Pada penelitian ini, modal sosial yang dimaksud mencakup orang-orang terdekat remaja, yaitu orang tua, guru, dan teman yang menjadi dasar bagi pengembangan alat ukur modal sosial remaja. Responden penelitian berjumlah 250 orang, di mana 46 persennya merupakan laki-laki. Berdasarkan hasil uji psikometri yang dilakukan, skala modal sosial bagi remaja diketahui memiliki validitas dan reliabilitas yang baik setelah diuji konsistensi internal dan validitas konstruknya. Skala ini dapat mengukur satu konstruk yang serupa dengan konstruk modal sosial, yaitu: Interaksi sosial (social interaction), kepercayaan (trust), dan visi bersama (shared vision). Dengan hasil uji psikometri yang cukup baik, maka skala ini dapat digunakan untuk mengukur modal sosial dalam konteks pada remaja.
\end{abstract}

Kata Kunci: remaja; skala modal sosial; psikometri; pengembangan skala 


\section{PENDAHULUAN}

Masa remaja merupakan masa seseorang beranjak dari masa kanak-kanak menuju dewasa. Masa remaja juga bisa dikatakan sebagai masa storm and stress (badai dan tekanan), di mana pada periode ini remaja mengalami konflik dan kontradiksi yang tidak terelakkan sehingga banyak memengaruhi perilakunya yang terlihat dalam pergaulan bersama orang-orang terdekatnya (Hurlock, 1999).

Dalam kehidupan sehari-hari, remaja memiliki lingkungan pergaulan yang menjadi modal sosialnya atau disebut juga modal sosial (social capital). Terkait dengan modal sosial, Collins dan Sprinthall (1995) menguraikan ada tiga pengaruh yang diperoleh dari keluarga, guru, dan teman dalam kehidupan sosial remaja sebagai berikut: Pertama, keluarga secara signifikan memengaruhi perkembangan remaja, bahkan sampai melampaui masa remajanya. Keluarga memiliki dampak yang luas bagi kehidupan remaja di luar keluarga, seperti dalam hubungannya dengan teman sebaya, guru, dan orang dewasa lainnya. Atmosfer emosional keluarga, yakni cara orang tua melatih dan mengajarkan anak-anaknya dapat membentuk arah masa depan kehidupan remaja. Kedua, guru memiliki peranan penting dalam membantu siswa belajar dengan memberikan tugas yang memerlukan keaktifan dan keterlibatan pribadi, memberikan bahan yang harus dipelajari, mengenali pribadi siswa, menanamkan nilai-nilai moral yang konsisten, serta memberikan prioritas tinggi untuk tujuan akademik dalam mengelola proses belajar-mengajar. Ketiga, sebelum remaja, anak-anak menghabiskan lebih banyak waktu dengan orang tua dibandingkan dengan anak-anak lain. Tetapi, pada saat remaja, mereka menghabiskan lebih banyak waktu dengan teman sebaya daripada dengan keluarga. Teman juga berkontribusi selama perkembangan masa remaja. Hubungan dengan keluarga, guru, dan teman adalah konteks yang paling penting untuk mengembangkan karakteristik pribadi dan pengetahuan sosial, serta keterampilan yang diperlukan remaja menuju dewasa. Selain pendapat tersebut, beberapa penelitian sebelumnya mengenai modal sosial terbukti berperan penting pada remaja sebagai akses dalam memberikan bantuan positif melalui jaringan hubungan yang lebih tahan lama dengan berbagai pihak mencakup orang tua, guru, dan teman (King \& Furrow, 2004; Lim \& Putnam, 2010; Uslaner, 1999).

Dari uraian di atas, peneliti melihat adanya suatu kebutuhan untuk mengukur modal sosial, secara khusus untuk remaja yang dipersepsikan terhadap orang-orang terdekatnya, yaitu orang tua, guru dan teman. Berdasarkan studi yang telah dilakukan, penelitian yang pernah mengkaji mengenai modal sosial pada remaja adalah penelitian King dan Furrow (2004). Hasilnya ialah 
bahwa modal sosial memediasi pengaruh religiositas terhadap perkembangan moral yang positif pada remaja. Artinya, remaja bukan hanya perlu membangun religiositas yang tinggi, tetapi juga perlu memerhatikan modal sosialnya agar dapat membentuk moral sejak masa mudanya. Dalam penelitan tersebut, King dan Furrow (2004) membagi tiga aspek dalam mengukur modal sosial, yaitu: Interaksi sosial (social interaction), kepercayaan (trust), dan visi bersama (shared vision). Namun sayangnya, ketiga aspek tersebut tidak dipersepsikan terhadap orang-orang terdekat remaja, sehingga pada kesempatan ini peneliti ingin mengembangkannya menjadi alat ukur modal sosial pada remaja yang dipersepsikan secara khusus kepada orang tua, guru, dan teman.

Oleh karena itu, tujuan dari penelitian ini adalah menyusun skala modal sosial untuk remaja yang valid, reliabel, dan tersusun atas butir-butir yang baik dengan standar psikometri yang sesuai dan bermanfaat untuk penelitian psikologi, khususnya psikologi sosial dan remaja.

\section{Pengertian Modal Sosial}

Setiap orang membutuhkan peranan orang lain dalam hidupnya agar dapat mencapai halhal yang diharapkan. Untuk itu, dibutuhkan modal sosial. Modal merupakan bekal yang dimiliki untuk mendapatkan sesuatu yang menguntungkan dan sosial merupakan sejumlah orang yang berhubungan dengan kehidupan seseorang. Modal sosial adalah sumber daya yang dapat dipandang sebagai investasi untuk mendapatkan sumber daya baru. Seperti diketahui, sumber daya adalah sesuatu yang dapat dipergunakan untuk dikonsumsi, disimpan, dan diinvestasikan. Sumber daya yang digunakan untuk investasi tersebut bisa disebut sebagai modal.

Boxman, De Graaf, dan Flap (1991) menyatakan bahwa modal sosial ditunjukkan ketika individu yang saling berhubungan secara positif dan memiliki berbagai sumber daya untuk diberikan secara cuma-cuma. Sejumlah individu dalam pengertian ini melibatkan pihak-pihak tertentu yang berperan dalam memberikan pengaruh positif, sedangkan sumber daya dalam pengertian ini dapat mencakup berbagai hal positif yang dapat diperoleh dari hubungan positif tersebut, seperti pengetahuan, keterampilan, dan sebagainya.

Organization for Economic Co-Operation and Development (OECD) (2001) mendefinisikan modal sosial sebagai kemampuan seseorang untuk memperoleh keuntungan dari keanggotaannya dalam jaringan sosial atau struktur sosial. Pemahaman ini mengindikasikan bahwa keterlibatan seseorang dalam hubungannya secara sosial dengan berbagai pihak ditujukan agar adanya timbal balik positif yang mendatangkan keuntungan bagi dirinya. 
Lebih lanjut, modal sosial berbeda dengan istilah populer lainnya, yaitu modal individual (human capital). Pada modal individual, segala sesuatunya lebih merujuk ke dimensi individu, yaitu daya dan keahlian yang dimiliki oleh individu. Pada modal sosial, penekanan lebih pada potensi kelompok dan antar kelompok dengan ruang perhatian pada jaringan sosial, nilai, norma, dan kepercayaan antar sesama yang lahir dari anggota kelompok dan menjadi norma kelompok (OECD, 2001). Istilah populer lainnya yang mirip dengan modal sosial adalah dukungan sosial. Dukungan sosial mengacu pada dukungan dari berbagai pihak yang berarti terhadap seseorang dalam bentuk bantuan-bantuan, seperti dukungan instrumental (materi), informasi, afiliasi, dan emosional (Barker, 2007). Sedangkan, modal sosial mengacu pada hubungan interpersonal yang dapat menciptakan nilai bagi diri seseorang (Coleman, 1988). Modal sosial dalam hal ini mengacu pada aktivitas seseorang yang ditujukan untuk mengembangkan hubungan dengan orang lain yang berpotensi untuk memberi pengaruh positif, aktif berpartisipasi dalam fungsi sosial, dan mengembangkan persahabatan dengan berbagai pihak (Feldman \& Ng, 2010).

Atencio dan Bearnes (2008) mengemukakan konsep modal sosial melibatkan kualitas dan agregasi hubungan sosial yang abadi dalam dan di antara masyarakat. Dalam hal ini, dapat dikatakan bahwa modal sosial meliputi kualitas dari satu kesatuan hubungan sosial yang mencakup ruang lingkup di dalam, seperti keluarga, dan ruang lingkup di luar, seperti sekolah (guru dan teman) serta masyarakat. Selanjutnya, Cox (1995) mendefinisikan modal sosial sebagai suatu rangkaian proses hubungan antar manusia yang ditopang oleh jaringan, norma-norma, dan kepercayaan sosial yang memungkinkan efisiensi dan efektivitas koordinasi serta kerja sama untuk keuntungan bersama. Pengertian ini merujuk bahwa dalam modal sosial terdapat norma-norma yang berlaku dan kepercayaan sosial dalam proses hubungan antar manusia untuk mendatangkan keuntungan satu sama lain.

Berdasarkan uraian-uraian di atas, dalam penelitian ini definisi modal sosial adalah berbagai pihak (orang tua, guru, dan teman) yang memiliki hubungan positif bagi diri seorang remaja.

\section{Unsur-Unsur Modal Sosial}

Mawardi (2007) mengemukakan inti telaah modal sosial terletak pada kemampuan masyarakat dalam suatu entitas atau kelompok untuk bekerja sama membangun suatu jaringan untuk mencapai tujuan bersama. Kerja sama tersebut diwarnai oleh suatu pola interelasi timbal balik yang saling menguntungkan dan dibangun di atas kepercayaan yang ditopang oleh normanorma dan nilai-nilai sosial yang positif dan kuat. Kekuatan tersebut akan maksimal jika didukung 
oleh semangat proaktif membuat jalinan hubungan di atas prinsip-prinsip yang disepakati. Adapun, unsur-unsur modal sosial menurut Mawardi (2007) adalah sebagai berikut.

Partisipasi dalam suatu jaringan. Modal sosial tidak dibangun hanya oleh satu individu, melainkan terletak pada kecenderungan yang tumbuh dalam suatu kelompok untuk bersosialisasi sebagai bagian penting dari nilai-nilai yang melekat. Modal sosial akan kuat tergantung pada kapasitas yang ada dalam kelompok untuk membangun sejumlah asosiasi berikut membangun jaringannya.

Timbal balik (reciprocity). Modal sosial senantiasa diwarnai oleh kecenderungan saling tukar kebaikan antar individu dalam suatu kelompok atau antar kelompok itu sendiri. Pola pertukaran ini bukanlah sesuatu yang dilakukan secara resiprokal seketika seperti dalam proses jual beli, melainkan suatu kombinasi jangka pendek dan jangka panjang dalam nuansa altruisme, yakni semangat untuk membantu dan mementingkan kepentingan orang lain. Individu dengan modal sosial yang tinggi memiliki semangat membantu yang lain tanpa mengharapkan imbalan seketika. Imbalannya tidak diharapkan seketika dan tanpa batas waktu tertentu. Hal ini juga direfleksikan melalui tingkat kepedulian sosial yang tinggi, saling membantu, dan saling memerhatikan.

Rasa percaya (trust). Rasa percaya mendorong seseorang berkeinginan untuk mengambil risiko dalam hubungan-hubungan sosial yang didasari oleh perasaan yakin bahwa yang lain akan melakukan sesuatu seperti yang diharapkan dan akan senantiasa bertindak dalam suatu pola tindakan yang saling mendukung, paling tidak yang lain tidak akan bertindak merugikan kelompoknya. Lebih lanjut, rasa percaya adalah sikap saling memercayai, saling bersatu dengan yang lain, dan memberikan kontribusi pada peningkatan modal sosial. Berbagai tindakan kolektif yang didasari atas rasa saling mempercayai yang tinggi akan meningkatkan partisipasi antar individu dalam berbagai ragam bentuk dan dimensi, terutama dalam konteks membangun kemajuan bersama. Kehancuran rasa saling percaya akan mengundang hadirnya berbagai masalah sosial yang serius. Jika rasa saling memercayai telah luntur, maka yang akan terjadi adalah sikap-sikap menyimpang dari nilai dan norma yang berlaku. Oleh sebab itu, rasa saling percaya sangat dibutuhkan dalam modal sosial.

Norma Sosial. Norma sosial akan sangat berperan dalam mengontrol bentuk-bentuk perilaku yang tumbuh dalam diri seseorang dan masyarakat. Norma adalah sekumpulan aturan yang diharapkan dipatuhi dan diikuti oleh anggota masyarakat pada suatu entitas sosial tertentu. Normanorma ini biasanya terinstitusionalisasi dan mengandung sanksi sosial yang dapat mencegah seseorang berbuat sesuatu yang menyimpang dari kebiasaan. Aturan kolektif tersebut biasanya tidak 
tertulis, tetapi dipahami oleh setiap anggota masyarakat dan menentukan pola tingkah laku yang diharapkan dalam konteks hubungan sosial.

Nilai-nilai. Nilai adalah suatu yang dianggap benar dan penting oleh anggota masyarakat, misalnya nilai harmoni, prestasi, kerja keras, dan kompetisi merupakan contoh nilai yang sangat umum dikenal dalam masyarakat. Nilai senantiasa memiliki kandungan konsekuensi yang ambivalen. Nilai harmoni, misalnya, yang oleh banyak pihak dianggap sebagai pemicu keindahan dan kerukunan hubungan sosial, tetapi di sisi lain dipercaya pula sebagai penghalang kompetisi dan produktivitas. Modal sosial yang kuat juga sangat ditentukan oleh konfigurasi yang tercipta pada suatu kelompok masyarakat. Jika suatu kelompok memberikan bobot tinggi pada nilai-nilai kompetensi, pencapaian, dan kejujuran, maka kelompok masyarakat tersebut cenderung jauh lebih cepat berkembang dan maju dibandingkan pada kelompok masyarakat yang senantiasa menghindari hal-hal tersebut.

\section{Domain Modal Sosial}

Dalam penelitian ini, luasnya tingkat analisis yang digunakan untuk mengukur modal sosial pada remaja yang dipersepsikan terhadap orang-orang terdekat, seperti: orang tua, guru, dan teman. Selanjutnya, King dan Furrow (2004) mengemukakan tiga domain yang terkait dengan luasnya tingkat analisis pengukuran modal sosial, antara lain interaksi sosial, rasa percaya, dan visi bersama.

Interaksi sosial (social interaction/SI) berkaitan dengan seberapa sering melakukan kegiatan bersama dan membangun komunikasi dalam setiap hubungan yang terjalin dengan orang tua, guru dan teman. Rasa percaya (trust/TS) berhubungan dengan hubungan yang ditandai oleh kepercayaan dan kedekatan dengan orang tua, guru dan teman. Visi bersama (shared vision/SV) berkaitan dengan mengenai berbagi nilai, dan tujuan dalam hubungan dengan orang tua, guru dan teman.

Dalam penelitian ini, peneliti menggunakan ketiga domain tersebut yang masing-masing dipersepsikan responden terhadap orang tua, guru, dan teman untuk mengukur modal sosial.

\section{METODE}

\section{Partisipan}

Partisipan penelitian ialah remaja berusia 15-18 tahun, bersekolah di kelas X-XI SMA/SMK dengan total responden sebanyak 250 orang (50 orang untuk uji coba dan 200 orang untuk uji analisis faktor dengan Second Order Confirmatory Factor Analysis). Proses pengambilan sampel 
dilakukan secara insidental, yaitu berdasarkan ketersediaan partisipan. Proses ini dilakukan dengan cara memberikan kuesioner pada para remaja yang ditemui peneliti, misalnya keluarga atau temanteman yang dapat dijangkau oleh peneliti dan bersedia mengisi kuesioner tersebut berdasarkan kriteria yang telah ditentukan. Dari segi jenis kelamin, partisipan perempuan (54\%) lebih banyak daripada partisipan laki-laki. Gambaran data partisipan tersaji dalam tabel di bawah ini.

Tabel 1.

Data Partisipan

\begin{tabular}{ccccc}
\hline \multirow{2}{*}{ Sekolah } & Kelas & Total & Laki-laki & Perempuan \\
\cline { 3 - 5 } & & 48 & 22 & 26 \\
& XMK & 64 & 34 & 30 \\
& XI & 60 & 26 & 34 \\
SMA & X & 78 & 33 & 45 \\
& XI & 250 & 115 & 135 \\
\hline
\end{tabular}

\section{Desain}

Penelitian ini merupakan penelitian kuantitatif. Dalam penelitian ini, modal sosial didefinisikan sebagai pihak-pihak (orang tua, guru, dan teman) yang memiliki hubungan positif bagi remaja yang disusun berdasarkan domain modal sosial sebagaimana dipersepsikan partisipan terhadap orang tua, guru, dan teman.

Skala modal sosial dibuat menggunakan instrumen penelitian dalam bentuk kuesioner yang butir-butirnya disusun sendiri oleh peneliti. Terdapat sebanyak 36 butir dan dilakukan validitas isi melalui penilaian pakar (expert judgement) psikologi pendidikan. Berdasarkan data yang diperoleh, peneliti kemudian melakukan analisis untuk melihat gambaran validitas dan reliabilitas dari skala modal sosial yang disusun. Berikut adalah blue print skala modal sosial.

Tabel 2.

Blue Print Skala Modal Sosial

\begin{tabular}{|c|c|c|c|c|}
\hline \multirow[t]{2}{*}{ No } & \multirow[t]{2}{*}{ Domain } & \multicolumn{2}{|c|}{ Nomor butir } & \multirow[t]{2}{*}{$\bar{\Sigma}$} \\
\hline & & Favorable & Unfavorable & \\
\hline 1 & $\begin{array}{l}\text { Interaksi Sosial } \\
\text { (Social Interaction; SI) }\end{array}$ & $1,7,13,19,25,31$ & $4,10,16,22,28,34$ & 12 \\
\hline 2 & $\begin{array}{l}\text { Rasa Percaya } \\
\text { (Trust, TS) }\end{array}$ & $2,8,14,20,26,32$ & $5,11,17,23,29,35$ & 12 \\
\hline \multirow[t]{2}{*}{3} & $\begin{array}{l}\text { Visi Bersama } \\
\text { (Shared Vision, SV) }\end{array}$ & $3,9,15,21,27,33$ & $6,12,18,24,30,36$ & 12 \\
\hline & & & Total & 36 \\
\hline
\end{tabular}




\section{Teknik Analisis}

Metode yang digunakan untuk menguji reliabilitas skala modal sosial ini adalah konsistensi internal melalui koefisien Cronbach's Alpha. Metode ini dipilih karena dapat melihat konsistensi internal butir-butir skala modal sosial dalam mengukur konstruk yang sama. Uji validitas yang dilakukan ialah validitas isi (content validity), validitas konstruk (construct validity), dan analisis faktor. Validitas isi dilakukan dengan penilaian oleh pakar. Validitas konstruk, yaitu menghubungkan modal sosial dengan perilaku prososial yang alat ukurnya diadaptasi dari penelitan Susanto (2017), di mana terdiri dari 12 butir dengan menggunakan skala Likert. Analisis faktor dilakukan dengan uji Second Order Confirmatory Factor Analysis. Uji ini dilakukan guna memodelkan hubungan antara variabel laten dengan variabel-variabel teramati yang bersifat congeneric, yaitu satu variabel teramati hanya mengukur sebuah variabel laten (Wijanto, 2008). Istilah lain yang dikemukakan oleh Hair, Black, Babin, dan Anderson (2010) mengenai hal ini ialah validitas diskriminan yang berguna untuk memastikan bahwa sebuah konstruk berbeda dengan konstruk lainnya dalam suatu model.

Dalam penelitian ini, guna melihat kecocokan model dalam uji CFA, maka ditetapkan indeks kecocokan dengan standar nilai, antara lain: RMSEA sebesar < .08, sedangkan NNFI, CFI, IFI dan GFI masing-masing sebesar > .9 (Wijanto, 2008).

Selain itu, construct reliability (CR) dan variance extracted (VE) didapatkan dengan CR sebesar $\geq .7$ dan VE sebesar $\geq .5$ (Wijanto, 2008). Perhitungannya dilakukan dengan rumus sebagai berikut.

$$
\begin{gathered}
C R=\frac{(\Sigma S L F)^{2}}{(\Sigma S L F)^{2}+\Sigma e} \\
V E=\frac{\Sigma S L F^{2}}{\Sigma S L F^{2}+\Sigma e}
\end{gathered}
$$

\footnotetext{
Keterangan:

CR (Construct Reliability) : konsistensi suatu pengukuran;

VE (Variance Extracted) : jumlah varian keseluruhan variabel manifes yang dijelaskan oleh variabel laten

$\sum S L F \quad$ : jumlah standard loading factor masing-masing butir

$\sum e \quad:$ jumlah eror masing-masing butir
} 


\section{Prosedur}

Remaja yang menjadi partisipan penelitian diberikan kuesioner penelitian menggunakan model skala Likert yang terdiri dari 36 butir dan memiliki dua bentuk pernyataan, yaitu favorable dan unfavorable. Terdapat lima alternatif pilihan jawaban dari model skala Likert dengan bobot skor 1-5 antara lain: Sangat Sesuai, Sesuai, Cukup Sesuai, Tidak Sesuai, dan Sangat Tidak Sesuai.

\section{ANALISIS DAN HASIL}

\section{Analisis Butir}

Butir-butir skala modal sosial dalam uji coba terdiri dari 36 pernyataan. Uji coba dilakukan kepada 50 partisipan yang terdiri dari 25 orang perempuan dan 25 orang laki-laki. Pada pengisian skala modal sosial versi uji coba, partisipan diminta untuk menilai sejauh mana pernyataan yang ditampilkan sesuai dalam menggambarkan dirinya dengan skala Likert. Berdasarkan hasil uji coba, diketahui nilai rata-rata sebesar $52.5(S D=5.29)$, serta $\alpha=.901$. Hal ini menunjukkan bahwa sebesar 90.1 persen varian berasal dari varian true score dan 9.9 persen merupakan varian eror yang berasal dari content sampling error dan content heterogeneity error. Dengan kata lain, butir-butir hasil uji coba skala modal sosial dapat mengukur satu konstruk yang sama.

Berdasarkan hasil uji corrected item-total, butir yang nilainya di bawah .3 dieliminasi karena dianggap sebagai butir yang buruk. Setelah mengeliminasi 12 butir yang buruk (butir nomor $1,2,4,5,7,8,10,11,33,34,35,36)$, peneliti memilih butir-butir dengan nilai korelasi paling baik (di atas .3) dan mengeliminasi dua butir lain (butir 6 dan 9) yang nilai corrected item-total-nya dibawah .3, sehingga skala modal sosial yang digunakan untuk pengambilan data utama terdiri dari 22 butir dengan sebesar 944 .

\section{Hasil Uji Psikometri}

Dalam penelitian ini, uji psikometri yang dilakukan adalah validitas konstruk dan analisis faktor dengan Second Order Confirmatory Factor Analysis.

\section{Validitas Konstruk}

Validitas yang digunakan adalah validitas konstruk dengan mengkorelasikan modal sosial dengan perilaku prososial. Variabel perilaku sosial dipilih karena keterkaitan remaja dengan lingkungan sosialnya dianggap dapat berkaitan dengan perilaku sosial remaja dalam kehidupannya 
sehari-hari. Argumentasi ini diperkuat oleh Uslaner (1999) yang mengemukakan bahwa modal sosial berkaitan dengan perilaku remaja yang dinyatakan dengan keterlibatan pihak-pihak tertentu yang memberikan kontribusi positif pada perilaku seseorang. Berdasarkan hasil penelitian ini, terdapat korelasi yang positif dan signifikan $(r=.644 ; p<.01)$ antara modal sosial dengan perilaku prososial remaja. Jadi, semakin seseorang memiliki modal sosial yang positif atau dapat mendukungnya, maka semakin mampu seseorang itu menampilkan perilaku prososial. Sebaliknya, semakin seseorang dikelilingi modal sosial yang negatif atau kurang mendukung, maka dapat berdampak buruk pada pada perilakunya.

\section{Analisis Faktor}

Uji analisis faktor skala modal sosial dengan CFA untuk menguji kesesuaian model (goodness of fit) terdiri dari 22 butir sebagai variabel teramati, tiga domain sebagai variabel laten tingkat pertama (Social Interaction/SI, Trust/TS, dan Shared Vision/SV), serta satu variabel laten tingkat kedua, yaitu modal sosial yang dibentuk dari ketiga variabel laten tingkat pertama. Hasil perhitungan analisis faktor konfirmatori ini menunjukkan data dengan model yang menghasilkan indeks kecocokan sebagai berikut.

Tabel 3.

Data Hasil Uji Model

\begin{tabular}{cccccccccc}
\hline \multicolumn{1}{c}{$\boldsymbol{x}^{\mathbf{2}}$} & $\boldsymbol{d} \boldsymbol{f}$ & $\boldsymbol{p}$ & RMSEA & NNFI & CFI & IFI & GFI & CR & VE \\
\hline $\mathbf{3 6 0 . 3 6}$ & 201 & 0.00 & 0.063 & 0.91 & 0.92 & 0.93 & 0.92 & 0.81 & 0.51 \\
\hline
\end{tabular}

Dari tabel di atas tampak bahwa model terakhir memiliki NNFI, CFI, IFI dan GFI sebesar > .90 dan RMSEA sebesar < .08 yang menunjukkan goodness of fit. Begitupun dengan nilai CR dan VE yang masing-masing berada di atas $\geq .7$ dan $\geq .5$. Namun, model ini masih belum memuaskan dengan $\chi^{2}$ dan $p<.01$. Jadi, secara umum dapat disimpulkan bahwa model ini cukup baik berdasarkan pada hasil indeks-indeksnya, namun masih membutuhkan analisis lebih lanjut untuk meningkatkan kecocokan keseluruhan model hingga dianggap memuaskan, dikarenakan butir-butir dalam model mengalami empat kali modifikasi error.

Figur 1 merangkum butir final, muatan faktor, $t$-value, serta model dari pengujian analisis konfirmatori. 


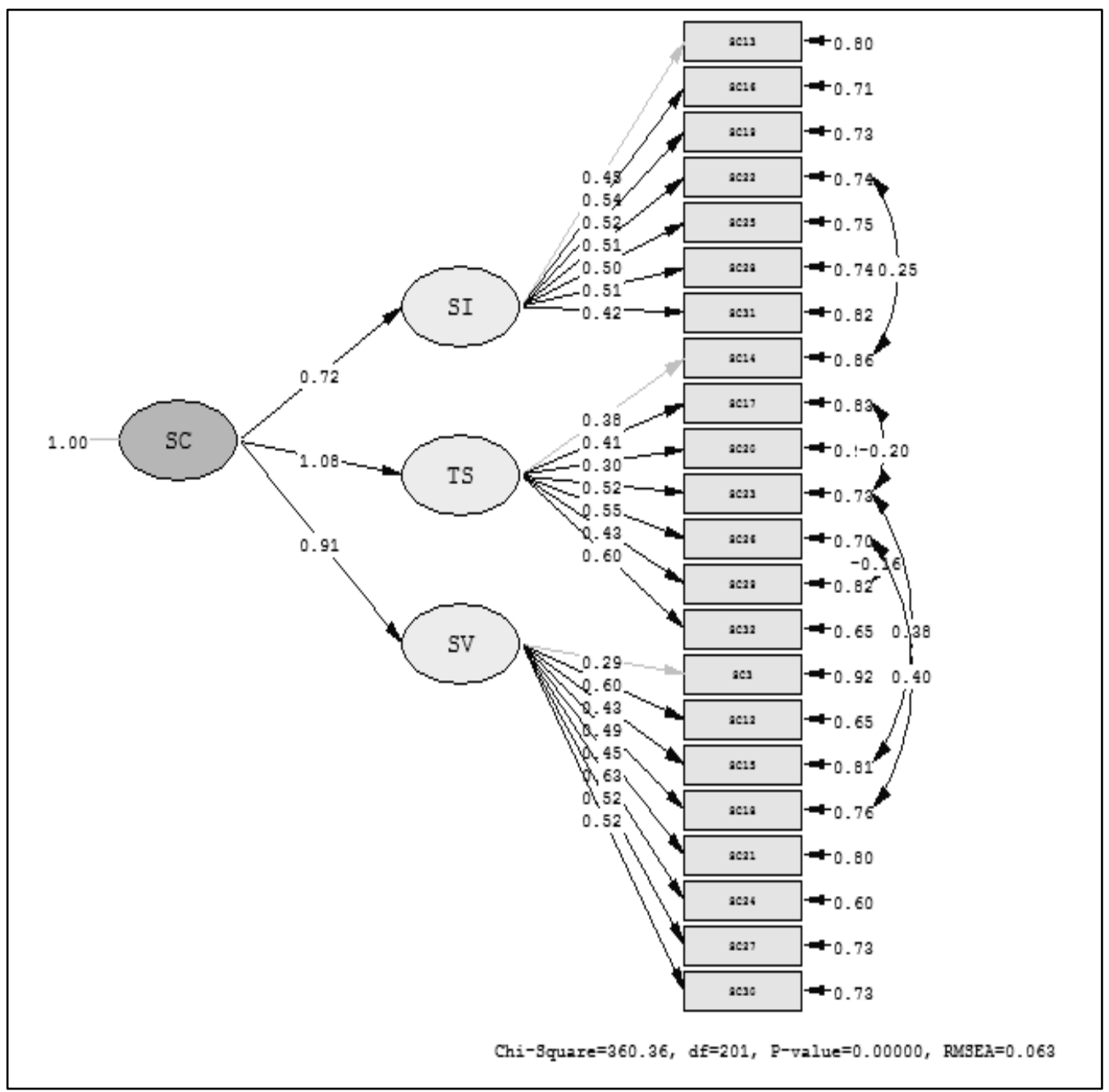

Figur 1. Muatan Faktor dan Interaksi antar Dimensi pada Skala Modal Sosial

Pada tabel 4, terlihat bahwa seluruh butir dalam skala memiliki muatan faktor yang baik $(M F>.3)$ di setiap domainnya. Begitupun dengan nilai $t$ semua butir yang telah memenuhi standar nilai sebesar > 1.96, sehingga dapat dikatakan bahwa butir-butir tersebut tergolong signifikan pada skala modal sosial. 
Tabel 4.

Butir-butir Skala Modal Sosial beserta Muatan Faktornya

\begin{tabular}{rlccc}
\hline Ind & Orang tua saya... & MF & $\boldsymbol{t}$ & Ket. \\
\hline S1 & ...menyediakan waktu untuk memberi nasihat & .45 & 4.67 & Sig \\
TS & ...memberi saya kepercayaan untuk melakukan kebaikan & .54 & 4.56 & Sig \\
SV & ...mengajari saya hal-hal yang baik & .52 & 4.54 & Sig \\
SI & ...sangat sibuk sehingga jarang bertemu & .51 & 4.50 & Sig \\
TS & ...memaksakan kemauannya untuk dituruti sekalipun & .50 & 4.55 & Sig \\
& melanggar aturan & & & \\
SV & ...tidak bisa menjadi teladan yang baik & .51 & 4.06 & Sig \\
SI & ...punya waktu untuk berlibur bersama keluarga & .42 & 4.53 & Sig \\
\hline Ind & Guru-guru saya.... & MF & $\boldsymbol{t}$ & Ket \\
\hline SI & ...mengajar dengan menjadi contoh bagi murid-muridnya & .38 & 3.92 & Sig \\
TS & ...yakin bahwa murid-muridnya dapat menjadi lebih baik & .41 & 3.22 & Sig \\
SV & ..mendorong murid-muridnya untuk mentaati peraturan & .30 & 4.43 & Sig \\
& sekolah & & & \\
S1 & ...mengabaikan perkembangan murid-muridnya & .52 & 4.53 & Sig \\
TS & ...merendahkan kemampuan murid-muridnya & .55 & 4.03 & Sig \\
SI & ...tidak memotivasi murid-muridnya untuk berprestasi & .43 & 4.67 & Sig \\
TS & ...dekat dengan murid-muridnya & .60 & 4.70 & Sig \\
\hline Ind & Saya dan teman-teman... & MF & $\boldsymbol{t}$ & Ket \\
\hline SI & ...melakukan kegiatan positif bersama & .30 & 3.57 & Sig \\
TS & ...saling mendukung untuk berbuat baik & .60 & 3.26 & Sig \\
SV & ...saling menasehati agar menghormati orang lain & .43 & 3.41 & Sig \\
SI & ...mengurusi dirinya masing-masing & .49 & 3.32 & Sig \\
TS & ...tidak dapat dipercayai & .45 & 3.62 & Sig \\
SV & ...tertutup satu sama lain & .63 & 3.46 & Sig \\
SI & ...menghabiskan waktu untuk bermain & .52 & 3.45 & Sig \\
TS & ...saling bisa menjaga rahasia & .52 & 3.45 & Sig \\
\hline
\end{tabular}

Keterangan: Ind (Domain) = SI (Social Interaction), TS (Trust), SV (Shared Vision); MF = muatan faktor; $\mathbf{S i g}=$ signifikan, $t>1.96$

\section{DISKUSI}

Berdasarkan analisis hasil, dapat dikatakan bahwa skala modal sosial yang disusun oleh peneliti sudah cukup memadai secara psikometri. Skala ini valid dalam mengukur konstruk modal sosial dan memiliki konsistensi internal yang baik. Dengan demikian, skala modal sosial untuk remaja ini sudah dapat digunakan dalam penelitian maupun intervensi di bidang psikologi. Dari uji model skala modal sosial, ditetapkan bahwa konstruk modal sosial terdiri dari tiga domain, yaitu interaksi sosial (social interaction), rasa percaya (trust), dan visi bersama (shared vision) (King \& Furrow, 2004). Dari hasil penelitan, domain terkuat adalah rasa percaya, yang berkaitan dengan hubungan yang ditandai oleh kepercayaan dan kedekatan dengan orang tua, guru, dan teman. Dengan kata lain, para remaja perlu mendapatkan rasa percaya dan kedekatan yang dapat 
mendukungnya untuk dapat menjadi lebih baik. Kedua adalah pentingnya visi bersama, yang mengenai berbagi nilai dan tujuan dalam hubungan dengan orang tua, guru, dan teman, sehingga remaja beroleh masukan-masukan yang positif dalam membangun dirinya. Selanjutnya adalah interaksi sosial, yang terkait tentang seberapa sering remaja melakukan kegiatan bersama dan membangun komunikasi dalam setiap hubungan yang terjalin dengan orang tua, guru, dan teman. Hal ini penting mengingat kualitas interaksi yang terjalin dengan orang tua, guru, dan teman dapat memengaruhi cara remaja bergaul, berkomunikasi, berpikir, dan berperilaku.

Hal yang menarik dalam penyusunan skala modal sosial yang dibuat dalam penelitian ini adalah lingkup modal sosial remaja yang diukur berdasarkan domain-domain yang dipersepsikan terhadap lingkungan terdekatnya, yaitu orang tua, guru, dan teman yang dalam penelitian modal sosial remaja sebelumnya tidak melibatkan persepsi terhadap orang tua, guru, dan teman dalam mengukur modal sosial (King \& Furrow, 2004). Namun, selain manfaat yang telah dihasilkan, masih terdapat beberapa keterbatasan dari skala modal sosial untuk remaja yang akan dikemukakan kemudian.

Berdasarkan hasil analisis, diketahui bahwa uji validitas konstruk yang digunakan oleh peneliti dalam melihat kesesuaian konstruk modal sosial dengan kriteria eksternal menggunakan skala lain (perilaku prososial) yang mengindikasikan keterkaitan modal sosial dengan konstruk lainnya. Ditemukan bahwa semakin seseorang memiliki modal sosial yang positif atau dapat mendukungnya, maka perilakunya semakin baik. Sebaliknya, semakin seseorang memiliki modal sosial yang negatif atau kurang mendukung, maka dapat berdampak buruk pada perilaku sosialnya. Hal ini sejalan dengan studi Uslaner (1999) bahwa modal sosial berkaitan dengan perilaku remaja yang dinyatakan dengan keterlibatan pihak-pihak tertentu yang memberikan kontribusi positif pada kehidupan seseorang. Hasil penelitian ini menunjukkan bahwa dengan siapa seseorang bergaul, orang-orang seperti apa yang memberi pengaruh terhadap dirinya, dan nilai-nilai apa yang ditanamkan dalam pergaulan akan memberi pengaruh terhadap perilaku seseorang.

Berdasarkan hasil analisis faktor konfirmatori, ditemukan bahwa model skala modal sosial menunjukkan indeks kecocokan model yang cukup baik berdasarkan sebagian besar indeks yang ada sebagaimana ditetapkan oleh Wijanto (2008). Seluruh butir dalam skala juga memiliki muatan faktor yang tergolong baik di setiap domainnya. Namun, guna meningkatkan hasil kecocokan model ke depannya perlu pengembangan lebih lanjut, di antaranya adalah jumlah sampel yang hanya berjumlah 200 orang dan juga adanya indikasi bahwa skala yang disusun tidak hanya memiliki tiga domain seperti yang dilakukan dalam penelitian ini. Oleh karena itu, perlu dilakukan 
pengujian kembali kepada sampel yang lebih besar dan representatif dan model skala dikembangkan hingga ditemukan indeks kecocokan model yang paling baik.

Terkait dengan pengembangan butir yang mungkin dilakukan, alat ukur ini secara khusus diperuntukkan bagi remaja yang dalam penelitian ini domain-domainnya dipersepsikan terhadap lingkungan terdekat remaja, yaitu orang tua, guru, dan teman. Oleh karena itu, penggunaan serta interpretasinya akan terbatas pada domain yang diukur.

\section{SIMPULAN DAN SARAN}

\section{Simpulan}

Studi penyusunan skala modal sosial yang disusun peneliti ini dapat dianggap memiliki standar psikometri cukup memadai. Hasil studi menunjukkan bahwa skala modal sosial memiliki validitas yang memadai, serta memiliki konsistensi internal yang baik. Skala modal sosial yang butir-butirnya disusun sendiri oleh peneliti juga mengukur satu konstruk yang sama secara konsisten dan cukup valid untuk mengukur konstruk modal sosial melalui tiga domain, yaitu interaksi sosial, rasa percaya, dan visi bersama yang dipersepsikan partisipan terhadap orang tua, guru, dan teman.

\section{Saran Teoretis}

Saran untuk penelitian selanjutnya adalah menambah jumlah partisipan, sehingga dapat lebih mewakili populasi dan data yang diperoleh dapat diolah menggunakan analisis faktor agar hasilnya lebih baik. Hal ini dikarenakan jumlah partisipan dinilai masih belum cukup untuk melakukan analisis faktor dan ada kemungkinan memengaruhi model yang dihasilkan. Selanjutnya, pemilihan partisipan sebaiknya lebih bervariasi, misalnya dilakukan di beberapa tempat karena setiap tempat memiliki karakteristik budaya pergaulan remaja, keluarga, dan guru yang berbedabeda, sehingga diperoleh sebaran proporsi yang bervariasi dan dapat merepresentasikan populasi yang dituju. Hal lainnya, yaitu adanya kemungkinan faktor yang mengindikasikan butir-butir modal sosial tidak hanya mencakup tiga domain, tetapi mungkin terdapat domain-domain lain yang belum diketahui oleh peneliti untuk mengindikasikan modal sosial. Oleh karena itu, pada penelitian selanjutnya perlu mengembangkan literasi terkait domain modal sosial. 


\section{Saran Praktis}

Berdasarkan hasil yang diperoleh, skala modal sosial ini sudah cukup memenuhi standar psikometri sehingga sudah dapat dimanfaatkan untuk mengukur modal sosial dalam konteks penelitian psikologi sosial dan remaja.

\section{REFERENSI}

Atencio, M., \& Bearnes, S. (2008). Building social capital through outdoor education. Journal of Adventure Education and Outdoor Learning, 8(2), 99-112. doi: 10.1080/14729670802256868

Barker, G. (2007). Adolescents, social support and help seeking behaviour: An international literature review and programme consultation with recommendations for action. Geneva: World Health Organization.

Boxman, E.A., De Graaf, P. M., \& Flap, H. D. (1991). The impact of social and human capital on the income attainment of Dutch managers. Journal of Social Networks, 13(1), 51-73. doi: 10.1016/0378-8733(91)90013-J

Coleman, J. S. (1988). Social capital in the creation of human capital. The American Journal of Sociology, 94, 95-120. doi:10.1086/228943

Collins, W. A., \& Sprinthall, N. A. (1995). Adolescent psychology: A developmental view. New York, NY: McGraw Hill.

Cox, E. (1995). A truly civil society. Sydney: ABC Books.

Feldman, D. F., \& Ng, T. W. (2010). The effects of organizational embeddedness on development of social capital and human capital. Journal of Applied Psychology, 95(4), 696-712. doi: $10.1037 / \mathrm{a} 0019150$

Hair, Jr., Black, W. C., Babin, B. J., \& Anderson, R. E. (2010). Multivariate data analysis: A global perspective (7th ed.). New Jersey: Pearson Prentice Hall.

Hurlock, E. B. (1999). Developmental psychology: A life-span approach. New York, NY: McGrawHill.

King, P. E., \& Furrow, J. L. (2004). Religion as a resource for positive youth development: Religion, social capital, and moral outcomes. Developmental Psychology, 40(5), 703-713. doi: 10.1037/0012-1649.40.5.703

Lim, C., \& Putnam, R. D. (2010). Religion, social networks, and life satisfaction. American Sociological Review, 75(6), 914-933. doi: 10.1177/0003122410386686 
Mawardi. (2007). Peranan social capital dalam pemberdayaan masyarakat. Komunitas Jurnal Pengembangan Masyarakat Islam, 3(2), 5-14.

Organisation for Economic Co-operation and Development. (2001). The well-being of nations: The role of human and social capital. Paris: OECD.

Susanto, D. (2017). Peran pola asuh demokratis, konformitas teman sebaya dan penggunaan situs jejaring sosial terhadap perilaku prososial melalui mediator kontrol diri (Disertasi tidak dipublikasikan). Universitas Persada Indonesia YAI, Indonesia.

Uslaner, E. M. (1999). Trust but verify: Social capital and moral behavior. Social Science Information, 38(1), 29-55. doi: 10.1177/053901899038001002

Wijanto, S. H. (2008). Structural Equation Modelling (SEM) dengan LISREL 8.8 konsep \& tutorial. Yogyakarta: Graha Ilmu. 